\title{
JNPH
}

Volume 7 No. 2 (Oktober 2019)

(C) The Author(s) 2019

\section{HUBUNGAN PERILAKU PSN PLUS DENGAN KEJADIAN DEMAM BERDARAH (DBD) DI DAERAH WILAYAH PUSKESMAS BASUKI RAHMAT KOTA BENGKULU}

\author{
RELATIONSHIP OF PLUS PSN BEHAVIOR WITH THE EVENT OF DENGUE \\ BLOOD FEVER (DHF) IN REGIONAL DISTRICT AREAS BASUKI RAHMAT \\ KOTA BENGKULU
}

\author{
ULLYA RAHMAWATI, MUALIM, FADILA HERDIANI \\ POLITEKNIK KESEHATAN KEMENTERIAN KESEHATAN BENGKULU, \\ JURUSAN KESEHATAN LINGKUNGAN \\ JALAN INDRAGIRI NOMOR 3 PADANG HARAPAN KOTA BENGKULU
}

Email: Ullya88.rahmawati@gmail.com

\begin{abstract}
ABSTRAK
Abstrak: Deman Berdarah Dengue (DBD) adalah penyakit virus yang berbahaya, Untuk mencegah penyebaran penyakitnya dapat menggunakan metode PSN Plus untuk mengurangi jumlah nyamuk.berdasarkan survei awal yang dilakukan dari 8 rumah diantaranya, 6 rumah masih berprilaku PSN Plus yang kurang. Tujuan penelitian ini adalah untuk mengetahui hubungan perilaku PSN Plus dengan kejadian Demam Berdarah Dengue di wilayah Puskesmas Basuki Rahmat Kota Bengkulu. Jenis penelitian ini adalah penelitian deskiptif analitik dengan rancangan case control.Subjek penelitian ini adalah semua orang yang terdaftar penyakit DBD di Wilayah Puskesmas Basuki Rahmat Kota Bengkulu.Dengan jumlah 52 orang positif DBD dan 52 negatif DBD. Didapatkan sebagian dari responden memiliki pengetahuan baik sebanyak 75 orang $(72,1 \%)$, sikap lebih dari sebagian bersikap positif (favourable) 66 orang $(63,5 \%)$, tindakan kurang baik oleh lebih dari sebagian atau 59 orang $(56,7 \%)$.Analisis data di uji dengan menggunakan metode Chi Square. Hasil uji Chi Square menunjukan adanya hubungan antara perilaku PSN Plus dengan kejadian DBD, pengetahuan p-value 0,032, sikap p-value 0,043 dengan OR: 2,5 dan tindakan p-value 0,048 dengan OR: 2,4. Diharapkan Masyarakat Dapat menambah wawasan masyarkat, meningkatkan kesadaran terhadap bahayanya penyakit DBD dan pentingnya melakukan pencegahan dengan menerapkan perilaku PSN Plus di kehidupan sehari-hari.
\end{abstract}

Kata Kunci: Perilaku, PSN Plus, DBD

\begin{abstract}
Abstrack: Dengue Hemorrhagic Fever (DHF) is a dangerous viral disease, To prevent the spread of the disease can use the PSN Plus method to reduce the number of mosquitoes. Based on the initial survey conducted from 8 houses approved, 6 houses still behaved in PSN Plus which were lacking. The purpose of this study was to study the relationship between PSN Plus and the incidence of Dengue Fever in the Basuki Rahmat Community Health Center, Bengkulu City. This type of research is descriptive analytic research with case control design. The
\end{abstract}


subjects of this study were all people who reported dengue in the Basuki Rahmat Community Health Center in Bengkulu City. With a total of 52 people positive for dengue and 52 positive dengue fever. It was found that most of the respondents had good knowledge as many as 75 people $(72.1 \%)$, attitudes were more than partially positive (beneficial) 66 people (63.5\%), unfavorable actions by more than half or 59 people $(56.7 \%)$ ). Data analysis using Chi Square method. Chi Square test results show the relationship between PSN Plus behavior and incidence of DHF, knowledge p-value 0.032, attitude p-value 0.043 with OR: 2.5 and action p-value 0.048 with OR: 2.4. It is hoped that the community can add to the community's insight, increase awareness of the dangers of dengue disease and emphasize the importance of improving by applying PSN Plus in everyday life.

\section{Keywords: Behavior, PSN Plus, DHF}

\section{PENDAHULUAN}

Deman BerdarahDengue (DBD) adalah penyakit virus yang berbahaya karena dapat menimbulkan kematian kasus dalam waktu beberapa hari. Vektor utama Deman BerdarahDengue adalah nyamuk..(Candra, 2010).

Menurut data WHO (2016), prevalensi penyakit DBD sebanyak2,2juta kasus pada tahun 2010. Di tahun 2015 prevalensi penyakit DBD sebanyak 3,2 juta kasus dan mengalami peningkatan sebanyak $31 \%$. Sekarang ini,penyakit Demam Berdarah Dengue sudah endemik dilebih dari 100 negara didunia.( Priesley, 2018)

Jumlah kasus Demam Berdarah DengueD ata dari Direktorat Pencegahan dan Pengendalian Penyakit Tular Vektor dan Zoonotik, Kemenkes RI, prevalensi DBD pada tahun 2015sebanyak 129,650 kasus DBD sebanyak 1,071 meninggal dunia. Pada tahun 2016 prevalensi DBD sebanyak 202,314 kasus lalu sebanyak 1,593 meninggal dunia. Di tahun 2017 terhitung sejak Januari hingga Mei prevalensi DBD sebanyak 17.877 kasus, dengan 115 orang yang meninggal dunia (Kemenkes,2017)

Kasus Demam Berdarah Dengue yang terjadi di Provinsi Bengkulu di tahun 2015 terdapat 925 kasus DBD.Di tahu 2016 terdapat 1,750 kasus. Dan di tahun 2017 terdapat 618 kasus. (Profil Kesehatan Provinsi Bengkulu, 2018).

Sementara jumlah kasus Demam Berdarah Dengue yang terjadi di wilayah
Puskesmas Basuki Rahmat pada tahun 2017 yang lalu, terdapat 32 kasus yang terkena DBD dan untuk tahun 2018 mengalami peningkatan kasus sebanyak $45 \%$ yaitu 59 kasus yang terkena penyakit DBD.(Data Puskesmas Basuki Rahmat 2018).

Kejadian Demam Berdarah Dengue tersebut dapat dipengaruhi oleh berbagai macam faktor, salah satu faktor yang mempengaruhi yaitu perilaku masyarakat dalam menjaga kebersihan lingkungan disekitarnya. Untuk mengatasi penyakit Demam Berdarah Dengue, dibutuhkan peran serta masyarakat untuk menekan kasus ini sangat menentukan.Salah satu pencegahan penyebaran penyakit Demam Berdarah Dengue, dengan metode PSN Plus yang merupakan aktivitas utama upaya pencegahan DBD yang melibatkan peranserta masyarakat. (Respati,2017)

Gerakan PSN Plusini sangat efektif dibanding dengan metode pencegahan Demam Berdarah Dengueyang lain karena Gerakan PSN Plus menghilangkan sarang tempat nyamuk Aedes aegypti bertelur sehingga tidak memberikan kesempatan nyamuk Aedes aegypti sebagai vektor demam berdarah untuk melanjutkan siklus kehidupan dari mulai telur,jentik,pupa,dan nyamuk dewasa atau tidak memberikan kesempatan untuk berkembang biak (Gifari, 2017).

\section{METODE PENELITIAN}

Penelitian ini dilakukan di wilayah Puskesmas Basuki Rahmat Kota Bnegkulu 
pada tanggal 11 April-Mei 2019, menggunakan rancangan penelitian deskiptif analitik dengan metodecase control dengan pendekatan retrospektif.

Populasi dalam penelitian ini adalah sebanyak 104 orangsebanyak 52 orang yang tercatat menderita DBDdan yang tidak tercatat menderita DBD sebanyak 52 orang. Sampel adalah sebagian dari keseluruhan populasi yang menjadi objek penelitian atau bagian yang diambil dari keseluruhan objek yang diteiti dan dianggap mewakili populasi. dan sampel dilakukan dengan menggunakan tehnik total sampling atau semua populasi. Instrumen yang digunakan untuk mengetahui dan meneliti adalah kuesioner yang berkaitan dengan PSN Plus

\section{HASIL PENELITIAN}

\section{a. Analisis univariat}

Tabel 1. Distribusi Frekuensi Pengetahuan Responden di Wilayah Puskesmas Basuki Rahmat Kota Bengkulu Tahun 2019.

\begin{tabular}{cccccc}
\hline \multirow{2}{*}{ No } & Tingkat & \multicolumn{2}{c}{ Kasus } & \multicolumn{2}{c}{ Kontrol } \\
\cline { 3 - 6 } & Pengetahuan & $\mathrm{f}$ & $\%$ & $\mathrm{~F}$ & $\%$ \\
\hline 1 & Kurang & 17 & 16.3 & 12 & 11.5 \\
\hline 2 & Baik & 35 & 33.7 & 40 & 38.5 \\
\hline & Jumlah & 52 & 50 & 52 & 50 \\
\hline
\end{tabular}

Berdasarlan tabel 1 diketahui bahwa dari 104 responden yang diteliti, sebagian dari responden yang memiliki tingkat pengetahuan Baik 75 (72.1\%).

Tabel 2. Distribusi Frekuensi Sikap Responden di Wilayah Puskesmas Basuki Rahmat Kota Bengkulu Tahun 2019

\begin{tabular}{cccccc}
\hline \multirow{2}{*}{ No } & \multirow{2}{*}{ Sikap } & \multicolumn{2}{c}{ Kasus } & \multicolumn{2}{c}{ Kontrol } \\
\cline { 3 - 6 } & & $\mathrm{f}$ & $\%$ & $\mathrm{~F}$ & $\%$ \\
\hline 1 & Favourable & 25 & 24 & 38 & 60.6 \\
\hline 2 & Unfavourable & 27 & 14 & 14 & 39.4 \\
\hline & Jumlah & 52 & 50 & 52 & 50 \\
\hline
\end{tabular}

Berdasarlan tabel 2 diketahui bahwa dari 104 responden yang diteliti, hampir sebagian dari responden $41 \quad(39.4 \%)$ Responden memiliki sikap yang negatif (unfavourable)

Tabel 3. Distribusi Frekuensi Tindakan Responden di Wilayah Puskesmas Basuki Rahmat Kota Bengkulu Tahun 2019

\begin{tabular}{cccccc}
\hline \multirow{2}{*}{ No } & \multirow{2}{*}{ Tindakan } & \multicolumn{2}{c}{ Kasus } & \multicolumn{2}{c}{ Kontrol } \\
\cline { 3 - 6 } & & $\mathrm{f}$ & $\%$ & $\mathrm{~F}$ & $\%$ \\
\hline 1 & Kurang Baik & 35 & 33.7 & 24 & 23.1 \\
\hline 2 & Baik & 17 & 16.3 & 28 & 26.9 \\
\hline & Jumlah & 52 & 50 & 52 & 50 \\
\hline
\end{tabular}

Berdasarlan tabel 3 diketahui bahwa dari 104 responden yang diteliti, hampir sebagian dari responden yang memiliki tingkat prilaku yang kurang baik 59 (56.7\%).

Tabel 4. Distribusi Frekuensi Kejadian DBD di Wilayah Puskesmas Basuki Rahmat Kota Bengkulu Tahun 2019

\begin{tabular}{cccc}
\hline No & Penyakit & Frekuensi & $\%$ \\
\hline 1 & DBD & 52 & $50 \%$ \\
\hline 2 & Tidak DBD & 52 & $50 \%$ \\
\hline & Jumlah & 104 & $100 \%$ \\
\hline
\end{tabular}

Berdasarkan tabel 4 diketahui bahwa dari 104 responden yang diteliti, yang memiliki penyakit DBD sebanyak 52 orang $(50 \%)$ dan yang tidak DBD sebanyak 52 orang (50\%)

\section{b. Analisis Bivariat}

Tabel 5. Hubungan tingkat pengetahuan dengan kejadian DBD di Wilayah Kerja Puskesmas Basuki Rahmat Kota Bengkulu Tahun 2019

\begin{tabular}{|c|c|c|c|c|c|}
\hline \multirow{3}{*}{$\begin{array}{c}\text { Tingkat } \\
\text { Pengetahua } \\
n\end{array}$} & \multicolumn{3}{|c|}{ Diagnosa } & \multirow{3}{*}{ Total } & \multirow{3}{*}{$\begin{array}{c}p- \\
\text { value }\end{array}$} \\
\hline & \multicolumn{2}{|c|}{ Kasus } & Kontrol & & \\
\hline & $\mathrm{N}$ & $\%$ & $\mathrm{n} \quad \%$ & & \\
\hline Baik & 35 & 33.7 & $40 \quad 38.5$ & $72.1 \%$ & \\
\hline Kurang & 17 & 16.3 & 1211.5 & $\overline{27.9 \%}$ & $0,3821.619$ \\
\hline Total & 52 & 50 & $52 \quad 50$ & $\overline{100 \%}$ & \\
\hline
\end{tabular}

Hasil analisis bivariat menggunakan uji Chi Square menunjukan bahwa pValue 382( 
$p<0,05)$ dengan nilai $\mathrm{OR}=1.619$, hal ini menunjukan Ha ditolak yang berartitidak ada hubungan antara tingkat pengetahuan dengan kejadian DBD di wilayah Puskesmas Basuki Rahmat Kota Bengkulu.

Tabel 6. Hubungan sikap dengan kejadian DBD di Wilayah Kerja Puskesmas Basuki Rahmat Kota Bengkulu Tahun 2019

\begin{tabular}{|c|c|c|c|c|c|c|}
\hline \multirow{3}{*}{ Sikap } & \multicolumn{3}{|c|}{ Diagnosa } & \multirow{3}{*}{\multicolumn{2}{|c|}{ al $\begin{array}{c}P \\
\text { Value }\end{array}$}} & \multirow{3}{*}{ OR } \\
\hline & \multicolumn{2}{|c|}{ Kasus } & Kontrol & & & \\
\hline & $\mathrm{N}$ & $\%$ & $\%$ & & & \\
\hline Favorablel & 25 & 24.0 & $38 \quad 36.5$ & $60.6 \%$ & & \\
\hline $\begin{array}{c}\text { Unfavorab } \\
\text { lel }\end{array}$ & 27 & 26.0 & $14 \quad 13.5$ & $39.4 \%$ & 0,016 & 2.931 \\
\hline Total & 52 & 50 & $52 \quad 50$ & $100 \%$ & & \\
\hline
\end{tabular}

Hasil analisis bivariat menggunakan uji Chi Square menunjukan bahwa $p$-value 0,016 ( $p<0,05)$ artinya ada hubungan yang bermakna antara sikap dengan kejadian DBD, dan nilai $\mathrm{OR}=2.931$ artinya sikap yang unfavorable memiliki resiko 2.931 kali lebih besar akan mengalami DBD di bandingkan dengan yang sikapnya Favorablel

Tabel 7. Hubungan Tindakan dengan kejadian DBD di Wilayah Kerja Puskesmas Basuki Rahmat Kota Bengkulu Tahun 2019

\begin{tabular}{|c|c|c|c|c|c|c|c|}
\hline \multirow{3}{*}{ Tindakan } & \multicolumn{4}{|c|}{ Diagnosa } & \multirow{3}{*}{\multicolumn{2}{|c|}{ Total }} & \multirow{3}{*}{ OR } \\
\hline & \multicolumn{2}{|c|}{ Kasus } & \multicolumn{2}{|c|}{ Kontrol } & & & \\
\hline & $\mathrm{N}$ & $\%$ & $\mathrm{n}$ & $\%$ & & & \\
\hline Baik & 17 & 16.3 & 28 & 26.9 & $43.3 \%$ & & \\
\hline Kurang & 35 & 33.7 & 24 & 23.1 & $56.7 \%$ & 0,048 & 2.40 \\
\hline Total & 52 & 50 & 52 & 50 & $100 \%$ & & \\
\hline
\end{tabular}

Hasil analisis bivariate menggunakan uji Chi Square menunjukan bahwa $p$ Value 0,048 $(p<0,05)$ artinya ada hubungan yang bermakna antara tindakan dengan kejadian $\mathrm{DBD}$, dan nilai $\mathrm{OR}=2.40$ artinya tindakan PSN Plus yang kurang memiliki resiko 2.40 kali lebih besar akan mengalami DBD di bandingkan dengan yang memiliki tindakan yang baik.

\section{PEMBAHASAN}

\section{a. Hubungan Tingkat Pengetahuan dengan Kejadian DBD}

Berdasarkan analisis data Chi Square dengan nilai $\mathrm{p}=382$ dengan nilai $\mathrm{OR}=$ 1.619, hal ini menunjukkan yang tidak ada hubungan antara tingkat pengetahuan PSN Plus dengan kejadian DBD di wilayah Puskesmas Basuki Rahmat Kota Bengkulu. Dengan tingkat pengetahuan yang positif DBD termasuk dalam kategori kurang dengan responden $17(16,3)$ dan yang berpengetahuan baik 35 responden $(33,7 \%)$ dengan jumlah responden 52 orang. Dan yang tidak DBD termasuk dalam kategori sebagian kecil responden 12 orang $(11.5 \%)$ dan yang berpengetahuan baik 40 responden $(38.5 \%)$ dengan jumlah responden 52 orang.

Adapun faktor yang dapat menyebabkan pengetahuan PSN Plus tidak berhubungan dengan kejadian DBD adalah walapun ada responden memiliki tingkat pendidikan yang rendah, tetapi banyak warga yang menerima informasi tentang DBD dan PSN Plus dari Pengetahuan tentang DBD juga diperoleh dari kabar berita tentang DBD yang tersiar di berbagai media massa atau penyuluhan petugas kesehatan. Media juga berperan penting dalam penyampaian informasi dan pengetahuan serta punya potensi untuk mempengaruhi pengetahuan masyarakat tentang DBD.

Hal penelitian ini juga sejalan dengan penelitian yang dilakukan oleh Amalia Nur Hafidhah (2019) dengan judul Hubungan Pengetahuan Pemberantasan Sarang Nyamuk (PSN) Vektor Demam Berdarah Dengue (DBD) Dan Kebiasaan Menggunakan Obat Anti Nyamuk Pada Ayah Dengan Keberadaan Jentik Nyamuk Aedes Aegypti Di Blulukan Colomadu, dengan hasil Hasil uji statistik Chisquare bahwa secara statistik tidak terdapat hubungan antara pengetahuan gerakan 3M Plus dengan keberadaan jentik nyamuk Aedes aegypti pada masyarakat di RW 06, Kelurahan Turangga, Kecamatan Lengkong, Kota Bandung dengan $\rho=0,49$ ( $\rho$ 
$>0,05)$.

\section{b. Hubungan Sikap Dengan Kejadian DBD}

Berdasarkan analisis data dengan Chi Square dengan nilai $\mathrm{p}=0,016$, hal ini menunjukkan Ha diterima yang berarti ada hubungan antara sikap dengan kejadian DBD di wilayah Puskesmas Basuki Rahmat Kota Bengkulu. Selain itu berdasarkan odss ratio seseorang yang melakukan sikap yang tidak mendukung atau Unfavorable tentang upaya pencegahan DBD memiliki resiko 2,931 kali lebih besar untuk menderita DBD dibandingkan dengan responden yang memiliki sikap mendukung.

Berdasarkan hal diatas, menurut Sang Gede Purnama (2013) berpendapat bahwa sikap seseorang akan mempengaruhi kecenderungan perilaku untuk bertindak. Orang yang tidak setuju dengan upaya pemberantasan sarang nyamuk lebih cenderung tidak peduli dengan kegiatan kebersihan lingkungan dan program PSN Plus. Sikap merupakan reaksi yang masih tertutup tidak dapat dilihat langsung.Sikap hanya dapat ditafsirkan dari perilaku yang nampak. Fungsi sikap belum merupakan tindakan, akan tetapi merupakan predisposisi perilaku. Apabila situasi memungkinkan, maka sikap akan terwujud dalam bentuk tindakan

Hal penelitian ini juga sejalan dengan penelitian yang dilakukan oleh Ni Nyoman Yunita Kusuma Bakta (2014) yang berjudul Hubungan Antara Pengetahuan dan Sikap Terhadap Perilaku Pemberantasan Sarang Nyamuk (PSN) Sebagai Pencegahan Demam Berdarah Dengue (DBD) Di Banjar Badung, Desa Melinggih, Wilayah Puskesmas Payangan, dengan hasil chi square menunjukkan terdapat hubungan antara pengetahuan dan sikap terhadap perilaku PSN sebagai pencegah DBD, dengan nilai signifikansi $(p)$ masing-masing $<0,0001$ dan $<0,0001$.

\section{c. Hubungan Tindakan Dengan Kejadian DBD}

Berdasarkan analisis data dengan Chi Square dengan nilai $\mathrm{p}=0,048$, hal ini menunjukkan Ha diterima yang berarti ada hubungan antara Tindakan perilaku PSN Plus untuk mencegah terjadinya penyakit DBD di wilayah Puskesmas Basuki Rahmat Kota Bengkulu.selain itu berdasarkan odss ratio seseorang yang melakukan tindakan yang kurangdalam perilaku PSN Plus dalam upaya pencegahan DBD memiliki resiko 2,40 kali lebih besar untuk menderita DBD dibandingkan dengan responden yang memiliki tindakan yang baik. Pada penelitian ini dapat dilihat bahwa yang tindakannya kurang dan tidak pernah menderita DBD baik responden/anggota keluarga yaitu sebanyak 24 responden $(31.1 \%)$.

Menurut Notoatmodjo (2012) untuk terwujudnya sikap menjadi perbuatan nyata diperlukan faktor yang mendukung atau kondisi yang memungkinkan. Ada 4 tingkatan dari tindakan atau praktik yaitu prepsi, responden terpimpin, mekanisme dan adaptasi, warga telah memiliki presepsi dan responden terpimpin yang baik tentang PSN Plus tetapi untuk mekanismenya untuk melakukan yang benar agar menjadi kebiasaan warga belum menerapkannya dalam sehari hari, hal ini di lihat dari banyaknya warga yang masih tidak menerapkan PSN Plus dalam kehidupannya seperti menggantung pakaian, tidak menggunakan kelambu, ditemukannya genangan air pada botol bekas dll.

Penelitian ini sejalan dengan penelitian Penelitian ini sesuai dengan penelitian yang dilakukan oleh Helly Conny Pangemanan (2016) dengan judul Hubungan Tindakan Pemberantasan Sarang Nyamuk (Psn) Dengan Kejadian Demam Berdarah Dengue (DBD) Di Desa Watutumou I, II \& III Wilayah Kerja Puskesmas Kolongan dengan nilai probabiitasnya $0,048(p$-value $<0,005)$.

\section{KESIMPULAN}

Berdasarkan hasil penelitian yang dilakukan di wilayah Puskesmas Basuki Rahmat Kota Bengkulu didapatkan responden 
1. Sebagian respondne memiliki tingkat pengetahuan Baik 75 (72.1\%), sebagian dari responden memiliki sikap yang positif (favourable) terhadap PSN Plus sebanyak $66(63,5 \%)$ responden, sebagian responden memiliki tindakan yang kurang baik terhadap tindakan PSN Plus sebanyak 59 $(56,7 \%)$ responden dan kejadian DBD dari 104 responden yang memiliki penyakit DBD sebanyak $52(50 \%)$ orang dan yang tidak DBD sebanyak 52 (50\%) orang.

2. Tidak ada hubungan antara pengetahuan dengan kejadian DBD di Wilayah Puskesmas Basuki Rahmat Kota Bnegkulu dengan nilai $p=0,382$,

3. Adanya hubungan antara sikap dengan kejadian DBD di Wilayah Puskesmas Basuki Rahmat Kota Bengkulu dengan nilai $p=0,043$ dengan OR : 2,5

4. Adanya hubungan antara tindakan dengan kejadian DBD di Wilayah Puskesmas Basuki Rahmat Kota Bengkulu dengan nilai $p 0,048$ dan OR : 2,4 .

\section{SARAN}

Diharapkan Bagi Peneliti Lain menjadi bahan pertimbangan yang ingin melakukan penelitian lebih lanjut dan menambah wawasan peneliti lainnya.

Diharapkan Bagi Pendidikan Dapat di jadikan sumber bacaan untuk menambah wawasan dan referensi sumber bacaan bagi pembaca di kemudian hari.

Diharapkan Bagi Masyarakat Dapat menambah wawasan masyarkat, meningkatkan kesadaran terhadap bahayanya penyakit DBD dan pentingnya melakukan pencegahan penyakit ini dengan menerapkan perilaku PSN Plus di kehidupan sehari-hari.

\section{DAFTAR PUSTAKA}

Amalia, N. H. (2019). Hubungan Pengetahuan Pemberantasan Sarang Nyamuk (PSN) Vektor Demam Berdarah Dengue (DBD) Dan Kebiasaan Menggunakan Obat Anti Nyamuk Pada Ayah Dengan
Keberadaan Jentik Nyamuk Aedes Aegypti Di Blulukan Colomadu. Skripsi, Universitas Muhammadiyah Surakarta.

Candra, A. 2010. Demam Berdarah Dengue : Epidemiologi, Patogenesis, dan Faktor Resiko Penular. Jurnal Aspirator. Vol 2(2): Hal 110-119

Gifari, A. 2017. Hubungan Tingkat Pengetahuan Dan Perilaku Gerakan 3M Plus Dengan Keberadaan Jentik Aedes aegypti. (online), ( http://proceeding. unisba.ac.id/index.php/BaMGMH/articl e/view/1261,di akses 16 Desember 2018 )

KemenKes. 2017.Kemenkes Optimalkan PSN Cegah Demam Berdarah Dengue (DBD). Jakarta.

Notoatmodjo, S. 2012.Promosikesehatan dan perilaku kesehatan.Jakarta : Rineka Cipta.

Nyoman, Y. K. 2014. Hubungan Antara Pengetahuan Dan Sikap Terhadap Perilaku Pemberantasan Sarang Nyamuk (PSN) Sebagai Pencegahan Demam Berdarah Dengue (DBD) Di Banjar Badung, Desa Melinggih, Wilayah Puskesmas Payangan. Jurnal Keperawatan. Vol. 7 (3): Hal 1-12.

Priesley, F. 2018. Hubungan Perilaku Pembrantasan Sarang Nyamuk Dengan Menutup, Menguras Dan Mendaur Ulang Plus(P SN M Plus) Terhadap Kejadian Demam Berdarah Dengue (DBD) Di Kelurahan Andalas,(online), ( http//jurnal.fk.unand.ac.id, diakses 16 Desember 2018 )

Respati. T. et al. (2017). Berbagai Faktor Yang Mempengaruhi Kejadian Demam Berdarah Dengue di Kota Bandung.Jurnal Aspirator. Vol 9(2): Hal 91-96. 